Discussion Papers of the

Max Planck Institute for

Research on Collective Goods

Bonn 2018/2

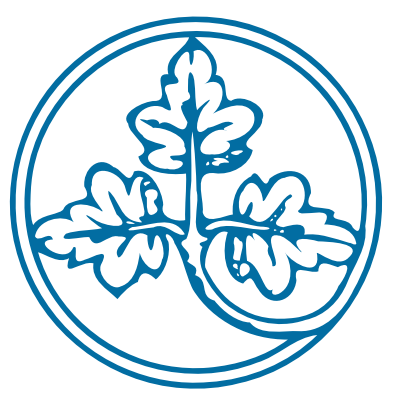

The Proper Scope of Behavioral Law and Economics

Christoph Engel

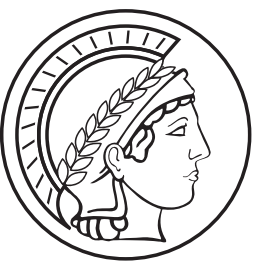




\section{The Proper Scope of Behavioral Law and Economics}

Christoph Engel

January 2018

Max Planck Institute for Research on Collective Goods, Kurt-Schumacher-Str. 10, D-53113 Bonn http://www.coll.mpg.de 


\title{
The Proper Scope of Behavioral Law and Economics
}

\section{Christoph Engel}

\begin{abstract}
Behavioral law and economics applies the conceptual tools of behavioral economics to the analysis of legal problems and legal intervention. These models, and the experiments to test them, assume an institution free state of nature. In modern societies, the law's subjects never see this state of nature. However a rich arrangement of informal and formal institutions creates generalized trust. If individuals are sufficiently confident that nothing too bad will happen, they are freed up to interact with strangers as if they were in a state of nature. This willingness dramatically reduces transaction cost and enables division of labor. If generalized trust can be assumed, simple economic models are appropriate. But they must be behavioral, since otherwise individuals would not want to run the risk of interaction.
\end{abstract}

* Helpful comments by Hanjo Hamann, Majbritt Sterba, and the participants of the 2017 EUI workshop on Theories of Choice, are gratefully acknowledged. 


\section{Epistemics and the Law}

Jurisprudentia, non juris scientia. ${ }^{1}$ Throughout the centuries, legal scholars have cautioned against defining their field as a science. ${ }^{2}$ The law has to govern people's lives. Legal decisions have direct consequences for the real world. And alas, reality is rich and unruly. But the law is not exempt from epistemology. All understanding is selective. It zeros in on one aspect of a much richer phenomenon. This one aspect can be rigorously defined. Rigorous definition is a precondition for reliable empirical investigation. One is able to formulate a theoretical claim about a causal relationship, and to test for its presence in some well-defined dataset. One may set a precise criterion for provisionally accepting the hypothesis, provided the counterhypothesis is sufficiently unlikely to be supported by the data.

Legal scholarship that is not content with establishing the internal consistency of a set of normative precepts ${ }^{3}$ therefore faces a dilemma. The legal scholar should only be confident of the correspondence ${ }^{4}$ between a claim about the world and the evidence if this claim is derived from theory, and tested according to the standards of the social sciences. However this same legal scholar will loathe being constrained by the architecture of the conceptual framework, and by the conventions of empirical research. How could she neglect an aspect of the underlying conflict of life, just because theory has not focused on it, data is insufficient, or standards of empirical research are excessively rigorous $?^{5}$ In the empirical disciplines, this conflict is often also presented as one between the internal validity of a test (the design safely excludes alternative explanations) and its external validity (the price for achieving internal validity is simplification; consequently what one studies is only analogous to what one wants to understand). ${ }^{6}$

1 Although this has not always been seen as a conflict. Digestas 1,1,10,2 (Ulpianus): „Iuris prudentia est divinarum atque humanum rerum notitia, iusti atque iniusti scientia“.

2 For a particularly powerful voice see Julius von Kirchmann, Die Wertlosigkeit Der Jurisprudenz Als Wissenschaft (Berlin: Springer, 1848). For a review of the book see Christoph Engel, "Julius Hermann Von Kirchmann: Die Wertlosigkeit Der Jurisprudenz Als Wissenschaft, Berlin 1848,"(2006).

3 As for instance the „Reine Rechtslehre“, Hans Kelsen, "Was Ist Die Reine Rechtslehre?," in Demokratie Und Rechtsstaat. Festgabe Zum 60. Geburtstag Von Zaccaria Giacometti(Zürich: Polygraphischer Verlag, 1953). On coherence theories of law see Barbara Baum Levenbook, "The Role of Coherence in Legal Reasoning," Law and Philosophy 3 (1984); Neil MacCormick, "Coherence in Legal Justification," in Theory of Legal Science, ed. Aleksander Peczenik(Dordrecht: Reidel, 1984); Aleksander Peczenik, "Law, Morality, Coherence and Truth," Ratio Juris 7 (1994).

4 For epistemic background see Marian David, "The Correspondence Theory of Truth," Stanford Encyclopedia of Philosophy (2010).

$5 \quad$ More on this conflict from Christoph Engel, "Empirical Methods for the Law," Journal of Institutional and Theoretical Economics 174 (2018).

6 There is an extended debate over external validity: see only Bobby J Calder, Lynn W Phillips, and Alice M Tybout, "The Concept of External Validity," Journal of Consumer Research 9, no. 3 (1982); Glenn H Bracht and Gene V Glass, "The External Validity of Experiments," American Educational Research Journal 5, no. 4 (1968); Craig A Anderson and Brad J Bushman, "External Validity of" Trivial" Experiments. The Case of Laboratory Aggression," Review of General Psychology 1, no. 1 (1997); John G Lynch Jr, "On the External Validity of Experiments in Consumer Research," Journal of consumer Research 9, no. 3 (1982); Jeffrey W Lucas, "Theory-Testing, Generalization, and the Problem of External Validity," Sociological Theory 21, no. 3 (2003); Arthur Schram, "Artificiality. The Tension between Internal and External Validity in Economic Experiments," Journal of Economic Methodology 12, 
Since this is a true dilemma, the gap between scientific research and reality will never be completely closed. But this is not to say that legal scholars should not care. They advise legal decision-makers. Whoever makes a decision has to take on responsibility. If the decisionmaker has serious doubts whether a scientific proposition is adequate for the case at hand, she will rightly put the proposition aside. But legal decision-makers, and their scholarly advisers, should not do so lightly. He who wants to see everything will see nothing. Selective attention is a precondition for seeing sharply. Ignoring scientific insights should be exceptional. Legal scholars should rather focus on the fit of proposed conceptual frameworks and supporting evidence with the conflict of life they are facing. Does the scientific concept zero in on the one aspect of the conflict that seems critical for the normative argument the lawyer wants to make?

Actually if they use this research strategy, their attitude is no different from the attitude of social scientists that advise policymakers. These scholars have coined the metaphor of a "zoo of models". ${ }^{7}$ If the object of your curiosity has a fur and four legs, you should not immediately take it to be a bear. It could also be a mouflon, a wolf, or a weasel. The metaphor suggests: each model, or concept more generally speaking, has its framework conditions. The model only helps make relevant statements about reality if there is a sufficiently good match between the model and the aspect of reality one is interested in. To stick with the example: if one is interested in sexual reproduction, it may suffice to broadly classify all these animals as mammals. But if one wants to understand in which habitat they have a chance to survive, more fine-grained distinctions are in order. Assessing the match between a model and the object of study, or the research question for that matter, is not a mechanical exercise. There is no meta-theory from which the conditions for applying some theory, or some empirical method for that matter, could be logically derived. Whether some theory has a good fit for the problem at hand is a matter of judgment.

Ultimately, judgment requires intuition. When it comes to selecting theoretical frameworks and empirical methods, this intuition should be professionally trained. ${ }^{8}$ The intuitive component should also not be radicalized. It usually will be possible to spell out the key reasons why some framework seems more adequate, and a competing framework seems less adequate. But the choice of framework, or of empirical method, cannot be proven to be right. The scholar must argue for her choice.

This is what the current paper sets out to do for an increasingly popular import from economics into law. It often is referred to as behavioral law and economics. In the next section I sketch the building blocks of the approach. It essentially is an extension of (neo) classical law

no. 2 (2005); Gregory Mitchell, "Revisiting Truth or Triviality. The External Validity of Research in the Psychological Laboratory," Perspectives on Psychological Science 7, no. 2 (2012).

7 Apparently, the metaphor has originally been coined by Helmut Bester. I owe it to Martin Hellwig. Physicists have even earlier colloquially talked about "the particule zoo", https://en.wikipedia.org/wiki/Particle_zoo.

8 Lorraine Daston calls the resulting epistemic ideal „truth“, to be distinguished from „objectivity“, Lorraine Daston and Peter Galison, Objectivity (New York; Cambridge, Mass.: Zone Books, 2007). 
and economics. It therefore inherits key concepts from economic (game) theory. Using a classic $2 \times 2$ prisoner's dilemma for illustration, in section $3 \mathrm{I}$ am asking whether this model has a good fit with the legal conflicts it is meant to elucidate. Section 4 concludes.

\section{Behavioral Law and Economics}

Behavioral law and economics is a sister of (neoclassical) law and economics. ${ }^{9}$ Both scholarly fields are interested in explaining the normative problems the law is meant to address, and legal intervention, with the reactions of individuals who strive for personal utility to constraints. In this perspective, a real-life conflict only calls for legal intervention if the socially detrimental action of one individual is not held in check by other individuals who also pursue their personal interests. Hence the approach relies on equilibrium analysis. It makes assumptions about individuals' utility functions and predicts outcomes in the absence of legal rules. It compares these outcomes with the prediction if the legal order intervenes in some welldefined manner. There is a case for legal intervention if the former state of affairs is further away from the social optimum than the latter, taking any pecuniary and non-pecuniary cost of the intervention into account.

The key difference between neoclassical and behavioral law and economics is the set of assumptions the analyst makes about the utility function of a representative member of society. ${ }^{10}$ While first-generation law and economics models often have assumed that individuals exclusively maximize personal monetary profit, ${ }^{11}$ behavioral models allow for richer definitions of utility, ${ }^{12}$ and in particular for social preferences. ${ }^{13}$ Other extensions concern the cognitive side of human behavior. They in particular allow individuals' reactions to changes in the opportunity structure to be imperfect. ${ }^{14}$

Neoclassical and behavioral law and economics have been particularly interested in cooperation problems. Such problems take their definition from welfare economics. ${ }^{15}$ This normative

9 For introductions see Eyal Zamir and Doron Teichman, The Oxford Handbook of Behavioral Economics and the Law (Oxford University Press, USA, 2014); Kathryn Zeiler and Joshua C. Teitelbaum, Research Handbook of Behavioral Law and Economics (Cheltenham: Edward Elgar, 2017).

10 Alternatively, the analyst may allow for heterogeneity, and will then predict outcomes conditional on assumptions about the type space.

11 See the classic manuals by Richard A. Posner, Economic Analysis of Law, 6th ed. (New York: Aspen Publishers, 2014); Robert Cooter and Thomas Ulen, Law and Economics, 4th ed. (Upper Saddle River: Prentice Hall, 2012).

12 For an overview see e.g. Colin F. Camerer, Behavioral Game Theory. Experiments in Strategic Interaction, 1. print. ed., The Roundtable Series in Behavioral Economics (New York, NY: Sage u.a., 2003); Roger Frantz et al., Routledge Handbook of Behavioral Economics (Routledge, 2016).

13 For an overview see Ernst Fehr and Klaus M. Schmidt, "The Economics of Fairness, Reciprocity and Altruism. Experimental Evidence and New Theories," Handbook on the Economics of Giving, Reciprocity and Altruism 1 (2006).

14 A good illustration are learning models, see e.g. Colin F. Camerer and Teck Hua Ho, "ExperienceWeighted Attraction Learning in Normal Form Games," Econometrica 67, no. 4 (1999).

15 For background see Allan M. Feldman, Welfare Economics and Social Choice Theory, 12. print. ed. (Boston: Kluwer u.a., 1997). 
branch of economic theory zeros in on one normative goal: allocative efficiency. Scarce resources should end up in the hands of those individuals that can use them most productively. This does not exclude trade. Efficiency need not be established right from the start. Actually one of the most important insights of this discipline is the Coase theorem. As long as property rights are well defined, contracts can be enforced, preferences are common knowledge, and transaction cost is zero, the initial allocation of property rights is immaterial. Through trade resources end up with those individuals who have the highest valuation for them. ${ }^{16}$ Of course, in many contexts of life these assumptions are heroic, which then justifies legal intervention.

A classic situation that does not fulfill these assumptions is a prisoner's dilemma. ${ }^{17}$ It assumes that two individuals who are in conflict with each other have to decide simultaneously whether to cooperate or to defect. Simultaneous choice rules out trade. Utilities are such that both individuals would collectively be best off if both of them cooperate. But individually each of them gets her highest utility if she defects while the other cooperates, and each of them gets her lowest utility if she cooperates while the other defects. If both defect, both get their second worst outcome. This is why defection is inefficient. The society of these two individuals would have higher welfare if both cooperate. But either of them has an incentive to defect.

The following table is the standard representation of the game. A row-player $\mathrm{R}$ interacts with a column-player $\mathrm{C}$. Each of them has a binary action set. They can either cooperate or defect. Utility is conditional on the choice made by the other player. The first number in each cell stands for R's utility, the second for C's utility. Payoffs are indicated ordinarily. Hence $4>3$ $>2>1$ holds. However the model does (in this version) not specify by how much one utility differs from the other. It does also not assume that utilities are equidistant. These additional assumptions are not necessary because players maximize utility. It is also not assumed that a utility of some level (say 3) is the same for each player. This additional assumption is not necessary since the numbers already reflect the overall individual assessment of the outcome. $\mathrm{C}$ may for instance be rivalistic and prefer a large over a small payoff gap. Such a preference does not change the equilibrium as long as this non-standard utility is not strong enough to change the order of the desirability of outcomes.

16 Ronald Coase, "The Problem of Social Cost," Journal of Law and Economics 3 (1960).

17 Lawyers interested in more background are referred to Douglas G. Baird, Robert H. Gertner, and Randal C. Picker, Game Theory and the Law (Cambridge, Mass.: Harvard University Press, 1994); Fritz Wilhelm Scharpf, Games Real Actors Play. Actor-Centered Institutionalism in Policy Research, Theoretical Lenses on Public Policy (Boulder, Colo.: Westview Press, 1997). 


\begin{tabular}{|c|c|c|c|}
\hline \multicolumn{2}{|c|}{} & \multicolumn{2}{c|}{ player C } \\
\cline { 2 - 4 } & cooperate & defect \\
\hline \multirow{2}{*}{ player R } & cooperate & 3,3 & 1,4 \\
\cline { 2 - 4 } & defect & 4,1 & 2,2 \\
\hline
\end{tabular}

Table 1

Prisoner's Dilemma

If the model correctly captures the conflict, the model makes a clear prediction. The outcome ranked highest (4) is preferred over the outcome ranked second-highest (3). This is why the individual defects if she assumes that her counterpart will cooperate. The outcome ranked third-highest (2) is preferred over the outcome ranked lowest (1). This is why the individual defects if she assumes that her counterpart will defect as well. In the game theory literature, the former motive is sometimes referred to as "greed", and the latter motive is sometimes referred to as "fear". ${ }^{18}$ Both motives support the same choice. Game theorists therefore call cooperation "dominated". This makes the prediction very robust. One need not know individuals' beliefs. It also does not matter whether they are uncertain about their opponent's choices. Even if the opponent were to randomize between both choices, their best response would not change.

This robustness of the prediction has led policy analysts to talk of the "tragedy of the commons". ${ }^{19}$ A fairly rich behavioral literature has investigated whether this prediction holds empirically, both in the $1 a b^{20}$ and in the field. ${ }^{21} \mathrm{We}$ have also ourselves contributed to this literature, and have found that, in the lab, the prisoner's dilemma is a game of multiple motives. Gains from cooperation, optimism, inequity aversion, risk aversion and loss aversion are all needed to explain choices in the prisoner's dilemma. ${ }^{22}$

18 K.T. Ahn et al., "Cooperation in Pd Games. Fear, Greed, and History of Play," Public Choice 106 (2001)..

19 Garrett Hardin, "The Tragedy of the Commons," Science 162 (1968).

20 See e.g. Anatol Rapoport and Albert M. Chammah, Prisoner's Dilemma. A Study in Conflict and Cooperation (Ann Arbor,: University of Michigan Press, 1965); Andrew M. Colman, "Cooperation, Psychological Game Theory, and Limitations of Rationality in Social Interaction," Behavioral and Brain Sciences 26 (2003); Ananish Chaudhuri, "Sustaining Cooperation in Laboratory Public Goods Experiments. A Selective Survey of the Literature," Experimental Economics 14, no. 1 (2011).

21 See e.g. Elinor Ostrom, Governing the Commons. The Evolution of Institutions for Collective Action, The Political Economy of Institutions and Decisions (Cambridge, New York: Cambridge University Press, 1990); Elinor Ostrom et al., eds., The Drama of the Commons(Washington: National Academy Press, 2002); Joseph Henrich and Robert Boyd, "'Economic Man' in Cross-Cultural Perspective. Behavioral Experiments in 15 Small-Scale Societies," Behavioral and Brain Sciences 28 (2005).

22 Christoph Engel and Lilia Zhurakhovska, "When Is the Risk of Cooperation Worth Taking? The Prisoner's Dilemma as a Game of Multiple Motives," Applied Economics Letters 23 (2016). 


\section{The Prisoner's Dilemma as a Tool for Legal Analysis}

Many conflicts of law lend themselves to an analysis in terms of a $2 \times 2$ prisoner's dilemma. ${ }^{23}$ Every citizen is best off individually if others constrain themselves for the sake of the environment, while she pollutes. ${ }^{24}$ Every citizen is best off individually if others obey traffic rules while she drives at her convenience. ${ }^{25}$ Every citizen is best off individually if others are vigilant and stand up against rule violations while she ignores the signs of disorder. ${ }^{26}$ Every citizen is best off individually if others respect her property while she appropriates whatever is appealing. ${ }^{27}$ But if no one protects the environment, no one follows traffic rules, no one keeps disorder in check, and no one respects property, the whole society is worse off. Everyone must find their individual ways to survive in a polluted environment, on chaotic streets, with the threat of violence and with property at the mercy of thieves. Some may be able to create their individual safety nets. But this is at best unnecessarily costly, and most likely quite imperfect.

Analyzing such conflicts of life in terms of the $2 \times 2$ prisoner's dilemma provides the law with a justification for sovereign intervention, and with a recipe for the design of legal rules. If the economic model is appropriate, the socially undesirable outcome results from the fact that individual and social well-being fall apart. This invites interventions that change incentives. Threatening heedless citizens with criminal sanctions, ${ }^{28}$ and the obligation to compensate victims for damages, ${ }^{29}$ are ways of doing this. This is also where behavioral insights become relevant. If the original model is appropriate, behavioral research informs legal policy about the

23 Game theorists sometimes argue that even a prisoner's dilemma is not institution free, in that the game is well-defined. I do not want to engage in this debate over semantics. I use the term institution free as free from interventions with the intention to overcome the social dilemma.

24 For background see e.g. Daniel W Bromley, Handbook of Environmental Economics (Blackwell Oxford, 1995).

25 On the relationship between individual rationality and rule following see e.g. Viktor Vanberg, "Rational Choice, Rule-Following and Institutions.'," in Rationality, Institutions and Economic Methodology, ed. Uskali Mäki, Bo Gustafsson, and Christian Knudsen(New York: Routledge, 1993); John C Harsanyi, "Rule Utilitarianism, Rights, Obligations and the Theory of Rational Behavior," in Papers in Game Theory, ed. John Harsanyi(Springer, 1982).

26 This result is referred to as the second order prisoner's dilemma, Toshio Yamagishi, "The Provision of a Sanctioning System as a Public Good," Journal of Personality and Social Psychology 51 (1986); Douglas D. Heckathorn, "Collective Action and the Second-Order Free-Rider Problem," Rationality and Society 1 (1989).

27 For a formal model see Gary Stanley Becker, "Crime and Punishment. An Economic Approach," Journal of Political Economy 76 (1968).

28 This is the rationale of the deterrence theory of criminal law, see e.g. Samuel Cameron, "The Economics of Crime Deterrence. A Survey of Theory and Evidence," Kyklos 41 (1988); Dieter Dölling et al., "Is Deterrence Effective? Results of a Meta-Analysis of Punishment," European Journal on Criminal Policy and Research 15, no. 1 (2009); Steven N. Durlauf and Daniel Nagin, "The Deterrent Effect of Imprisonment," in Making Crime Control Pay. Cost-Effective Alternatives to Incarceration, ed. Philip J. Cook, Jens Ludwig, and Justin McCrary(Chicago: Chicago University Press, 2011); Paul H. Robinson and John M. Darley, "Does Criminal Law Deter? A Behavioural Science Investigation," Oxford Journal of Legal Studies 24 (2004).

29 This is the rationale for the deterrence theory of torts, see W. Jonathan Cardi, Randall D. Penfield, and Albert H. Yoon, "Does Tort Law Deter Individuals? A Behavioral Science Study," Journal of Empirical Legal Studies 9 (2012); Theodore Eisenberg, "Measuring the Deterrent Effect of Punitive Damages," Georgetown Law Journal 87 (1998); Theodore Eisenberg and Christoph Engel, "Assuring Civil Damages Adequately Deter. A Public Good Experiment," Journal of Empirical Legal Studies 11 (2014). 
underlying social problem, and helps it design better interventions. If social preferences are sufficiently strong and robust, what looks like a prisoner's dilemma in payoff space may not be one in utility space. ${ }^{30}$ As long as the dilemma does not become salient, citizens may also not immediately grasp the dilemma structure of the conflict and maintain a socially beneficial cooperation routine. ${ }^{31}$ If a sufficient fraction of the population holds at least weak social preferences, imperfect sanctions may compensate for this weakness, rather than being pointless (which they would for hard-nosed profit maximizers). ${ }^{32}$

But is it appropriate to analyze such conflicts of life in terms of a $2 \times 2$ prisoner's dilemma? The match seems intuitive. But does it abstract from elements of reality that are critical for the normative assessment and reaction? The model makes a lot of assumptions. Interaction is anonymous. There is no communication. It is not possible to solve the conflict by agreement. There is no room for third-party intervention. Interaction is one-shot. It is an interaction between only two individuals. Each individual has two make a yes or no decision, and cannot make intermediate choices. There are no dynamics.

All these assumptions matter for the dissolution of cooperation problems. Individuals are less selfish if they are identified. ${ }^{33}$ Communication increases the willingness to take others' legitimate interests into account. ${ }^{34}$ If people are able to choose their partners, or are matched to similar partners, they cooperate more. ${ }^{35}$ A credible threat with third-party intervention almost perfectly removes the dilemma. ${ }^{36}$ If the interaction is repeated (and the end of the relationship is uncertain), theory predicts multiple equilibria, including perfect cooperation. ${ }^{37}$ If the indi-

30 For this modelling strategy see e.g. John Geanakoplos, David W. Pearce, and Ennio Stacchetti, "Psychological Games and Sequential Rationality," Games and Economic Behavior 1, no. 1 (1989).

31 On inertia resulting from routines see Tilmann Betsch et al., "Has the World Changed? My Neighbor Might Know. Effects of Social Context on Routine Deviation," Journal of Behavioral Decision Making 28 (2014).

32 Christoph Engel, "Social Preferences Can Make Imperfect Sanctions Work. Evidence from a Public Good Experiment," Journal of Economic Behavior \& Organization 108 (2014).

33 Terence C. Burnham, "Engineering Altruism. A Theoretical and Experimental Investigation of Anonymity and Gift Giving," ibid.50 (2003); Martin Dufwenberg and Astri Muren, "Generosity, Anonymity, Gender," ibid.61 (2006); Francisco Alpizar, Fredrik Carlsson, and Olof Johansson-Stenman, "Anonymity, Reciprocity, and Conformity. Evidence from Voluntary Contributions to a National Park in Costa Rica," Journal of Public Economics 92, no. 5 (2008).

34 Daniel Balliet, "Communication and Cooperation in Social Dilemmas: A Meta-Analytic Review," Journal of Conflict Resolution 54, no. 1 (2010); Oliver Bochet, Talbot Page, and Louis Putterman, "Communication and Punishment in Voluntary Contribution Experiments," Journal of Economic Behavior \& Organization 60 (2006); Vincent Crawford, "A Survey of Experiments on Communication Via Cheap Talk," Journal of Economic Theory 78, no. 2 (1998).

35 Simon Gächter and Christian Thöni, "Social Learning and Voluntary Cooperation among Like-Minded People," Journal of the European Economic Association 3, no. 2-3 (2005).

36 Josef Falkinger et al., "A Simple Mechanism for the Efficient Provision of Public Goods. Experimental Evidence," American Economic Review 90 (2000).

37 Robert J. Aumann, Michael Maschler, and Richard E. Stearns, Repeated Games with Incomplete Information (Cambridge, Mass.: MIT Press, 1995). Empirically, results are less simple. If there is no institutional backing, cooperation tends to decrease over time. If there is room for disciplining free-riders, for instance by individuals engaging in costly punishment, it increases over time Ernst Fehr and Simon Gächter, "Cooperation and Punishment in Public Goods Experiments," American Economic Review 90 (2000). 
vidual dilemma is embedded in a social context, social norms matter more. ${ }^{38}$ Individuals tend to cooperate incompletely, ${ }^{39}$ and are therefore more likely to cooperate if they are not facing a yes or no decision. Cooperation is a social phenomenon that evolves over historical time. ${ }^{40}$

It seems that all these assumptions are violated if the prisoner's dilemma is used to analyze legal problems. Individuals either know each other in the first place, or they could at least find out. Before they let a conflict escalate, they could talk to each other. Private law makes it possible to write contracts on almost anything, and certainly on promises that make the world a better place. Such contracts can be enforced in court. Even if individuals do not rely on the legal system, they can exploit the fact that they interact with each other repeatedly. This makes it possible to build reputation. None of the conflicts listed at the beginning of this section is between just two individuals. All of them engage large communities. All conflicts happen in historical time and context, so that there is room for socially desirable solutions to evolve. Seemingly, modeling these conflicts of life as $2 \times 2$ prisoner's dilemmas is therefore grossly misplaced. These conflicts of life seemingly are just not the right habitat for the model. The legal analyst should search for another animal in the zoo of models that is better adapted to these living conditions.

Yet I want to claim that this conclusion should not be drawn. Modern societies are characterized by a pronounced degree of generalized trust. ${ }^{41}$ Most individuals are willing to engage with strangers, even in the absence of formal institutional safeguards against the risk of being taken advantage of. Generalized trust has multiple sources, including the family ${ }^{42}$, civil society $^{43}$ and the fabric of neighborhoods. ${ }^{44}$ It has been shown to react to personal experience, ${ }^{45}$ which is why immigrants tend to adopt the degree of generalized trust in high-trust countries. ${ }^{46}$ And, most importantly for the present context, there is a relationship between formal

38 On conditions for and the effect of guilt aversion see e.g. Martin Dufwenberg, Simon Gächter, and Heike Hennig-Schmidt, "The Framing of Games and the Psychology of Play," Games and Economic Behavior 73 (2011).

39 Urs Fischbacher and Simon Gächter, "Social Preferences, Beliefs, and the Dynamics of Free Riding in Public Good Experiments," American Economic Review 100 (2010).

40 Joseph Henrich and Robert Boyd, eds., Foundations of Human Sociality. Economic Experiments and Ethnographic Evidence from Fifteen Small-Scale Societies, 1. publ. ed.(Oxford: Oxford Univ. Press, 2004).

41 For cross-country comparisons see Christian Bjørnskov, "Determinants of Generalized Trust. A CrossCountry Comparison," Public choice 130, no. 1 (2007); Pamela Paxton, "Association Memberships and Generalized Trust. A Multilevel Model across 31 Countries," Social Forces 86, no. 1 (2007); Tim Reeskens and Marc Hooghe, "Cross-Cultural Measurement Equivalence of Generalized Trust. Evidence from the European Social Survey (2002 and 2004)," Social Indicators Research 85, no. 3 (2008). Eric M Uslaner, "Where You Stand Depends Upon Where Your Grandparents Sat. The Inheritability of Generalized Trust," Public Opinion Quarterly 72, no. 4 (2008).

43 Paxton, "Association Memberships and Generalized Trust. A Multilevel Model across 31 Countries.".

44 Melissa J Marschall and Dietlind Stolle, "Race and the City. Neighborhood Context and the Development of Generalized Trust," Political Behavior 26, no. 2 (2004).

45 Jennifer L Glanville and Pamela Paxton, "How Do We Learn to Trust? A Confirmatory Tetrad Analysis of the Sources of Generalized Trust," Social Psychology Quarterly 70, no. 3 (2007); Paul AM Van Lange, "Generalized Trust. Four Lessons from Genetics and Culture," Current Directions in Psychological Science 24, no. 1 (2015).

46 Peter Thisted Dinesen and Marc Hooghe, "When in Rome, Do as the Romans Do. The Acculturation of Generalized Trust among Immigrants in Western Europe," International Migration Review 44, no. 3 
legal institutions and the level of generalized trust in a country. ${ }^{47}$ If a country is characterized by high generalized trust, typically appropriate formal institutions and perceived trust are complements. ${ }^{48}$ They reinforce each other. ${ }^{49}$ Important institutional determinants include the perceived honesty of public officials, democratic representation, policies caring for the needs of the less affluent, ${ }^{50}$ the reliability of property rights, and labor market institutions. ${ }^{51}$

Through these channels, pervasive institutional intervention ensures that individual citizens are empowered, and oftentimes even forced to decide as if they were engaged in a naked $2 \times 2$ prisoner's dilemma with every other member of society. ${ }^{52}$ I argue that this is both the purpose and the socially most beneficial effect of the institutional fabric of modern societies. Individuals are freed up to interact as if they were in a state of nature with most other citizens most of the time. Despite the fact that it will technically often be possible to create an explicit and formal ad hoc regime, most of the time most individuals choose not to. This willingness to engage with strangers is an important source of wealth that distinguishes modern from more traditional societies. It enables exponentially more complex social relations, and a much more progressed division of labor.

Note that, ironically, it is precisely heavy and multi-faceted institutional intervention that makes it possible for individuals to interact as if they were in an institution free environment. But for the most part these rich institutional arrangements serve a different purpose. They do not align individual with social rationality in the individual, ad hoc relationship with a stranger. Rather they create and sustain a degree of generalized trust that frees individuals up to interact with strangers on the spot, despite the fact that they have no guarantee that these strangers will act cooperatively.

Let me substantiate this claim for the first assumption, anonymity. In modern societies it is often technically impossible, prohibitively costly or normatively undesirable to learn the identity of an interaction partner. It is technically impossible if interaction is on the spot, as on the streets. Finding out who has contributed to a degradation of air is not possible because contri-

(2010). Peter Thisted Dinesen, "Parental Transmission of Trust or Perceptions of Institutional Fairness. Generalized Trust of Non-Western Immigrants in a High-Trust Society," Comparative Politics 44, no. 3 (2012).

47 Bo Rothstein and Dietlind Stolle, "The State and Social Capital. An Institutional Theory of Generalized Trust," ibid.40, no. 4 (2008); Peter Thisted Dinesen, "Where You Come from or Where You Live? Examining the Cultural and Institutional Explanation of Generalized Trust Using Migration as a Natural Experiment," European Sociological Review 29, no. 1 (2011).

48 Blaine G Robbins, "Neither Government nor Community Alone. A Test of State-Centered Models of Generalized Trust," Rationality and Society 23, no. 3 (2011).

49 "Institutional Quality and Generalized Trust. A Nonrecursive Causal Model," Social Indicators Research 107, no. 2 (2012).

50 Markus Freitag and Marc Bühlmann, "Crafting Trust. The Role of Political Institutions in a Comparative Perspective," Comparative Political Studies 42, no. 12 (2009).

51 Blaine G Robbins, "A Blessing and a Curse? Political Institutions in the Growth and Decay of Generalized Trust. A Cross-National Panel Analysis, 1980-2009," PloS One 7, no. 4 (2012).

52 A related claim has been made by Kim Mannemar Sønderskov, "Explaining Large-N Cooperation. Generalized Social Trust and the Social Exchange Heuristic," Rationality and Society 23, no. 1 (2011); Kim Mannemar Sønderskov, "Different Goods, Different Effects. Exploring the Effects of Generalized Social Trust in Large-N Collective Action," Public Choice 140, no. 1-2 (2009). 
butions to the social harm are diffuse. ${ }^{53}$ In an open society, immigrants benefit from public goods, and it is ex ante not clear who might engage in socially undesirable behavior at a later point. Finally, many actions of those living today impact on the quality and the quantity of public goods enjoyed by future generations. Since they are not yet born, they also cannot have a say on today's choices.

Even if the identity of an interaction partner could technically be verified, in modern societies this is often prohibitively costly. Take a franchise chain. Bad behavior by any franchisee can jeopardize brand-name capital. But if the franchise chain is large, no individual member can afford to monitor the behavior of all other members. The cost argument is even more compelling on the Internet. The gains from trade for most micro-transactions would be below the cost of verifying identity.

Finally for competing normative reasons the legal order not so rarely guarantees anonymity. This for instance holds for whistleblowers, for job applicants if there is a concern about discrimination, for participants in manifestations that shall not be deterred by a chilling effect, or for privacy reasons. The police will for instance usually not disclose the name and address registered for the number plate of a car.

For the same list of reasons, communication between members of society is often not feasible before both of them take action. This can again be technically impossible, for instance among those participating in street traffic. It can be prohibitively costly, for instance among those engaging in micro-transactions over the Internet. And it can be normatively undesirable, for instance between a potential employer and a job applicant. If there is no communication, there is also no room for an ex-ante agreement. In situations that force anonymity, third-party intervention is impractical; it would at minimum require that the defendant is identified. Since individuals do not know with whom they interact, no long-term relationship may be formed. There is no room for the evolution of a relationship specific regime.

The foregoing considerations show that in modern societies it is not rare that individuals interact with each other in a way that is essentially the same as interaction among two strangers in a state of nature. To the extent that this seems an appropriate model, the legal assessment of the need for intervention, and the design of interventions, can be guided by economic thinking about the simultaneous $2 \times 2$ prisoner's dilemma. If this is the case, behavioral research becomes critical. As I have explained, the model is appropriate since a complex arrangement of formal and informal institutions has created generalized trust. It would be surprising if individuals were widely willing to trust an environment in which they stand a serious risk of being exploited. Now this is what neoclassical theory predicts for a simultaneous $2 \times 2$ prisoner's dilemma. Generalized trust is only a plausible source of tolerating a quasi state of nature if it

53 On the importance of diffuse relationships see Mancur Olson, The Logic of Collective Action. Public Goods and the Theory of Groups, Harvard Economic Studies, V. 124 (Cambridge, Mass.: Harvard University Press, 1965). 
comes with sufficiently strong behavioral qualifications that contain the risk of exploitation. ${ }^{54}$ Hence my argument makes a case for behavioral law and economics, while it does not for neoclassical law and economics. ${ }^{55}$

While there is thus scope for behavioral law and economics (of the simultaneous $2 \times 2$ prisoner's dilemma), this model is not appropriate for the legal analysis of each and every relationship that can be modeled this way. The model is for instance inappropriate if the parties to the interaction are easily identified. One area for which this holds is financial stability. Instability may result from the choices of financial intermediaries fighting against each other for profit. But the number of relevant players is small in these markets. They are relatively easy to identify. To the extent that antitrust does not make this illegal, these players might contain the dilemma by ex-ante contractual arrangements. The financial markets are of course institutionally embedded. But arguably these institutions are not meant to create generalized trust among financial intermediaries. On the other hand, the behavioral effects that help reduce the risk of exploitation among individuals are at least not directly applicable to the decisions made on behalf of financial intermediaries as complex legal entities. ${ }^{56}$

But for other conflicts of law a behavioral law and economics approach that models the interaction as a simultaneous $2 \times 2$ prisoner's dilemma has a considerably better fit. This holds for problems that are typically addressed by public law, like most problems of environmental law. It holds for problems typically addressed by private law, like the governance structure of a franchise chain. And it holds for problems typically address by criminal law, like rule following.

\section{The Proper Scope of Behavioral Law and Economics}

Behavioral law and economics is an interdisciplinary venture. It capitalizes on the burgeoning field of behavioral and experimental economics. To a considerable degree, the power of behavioral economics originates in its rigor. Most of the experimental evidence has been generated as tests of models that modify economic games. These models either assume utility functions that transcend profit maximization, or they assume well-defined, non-standard ways of

54 Kim Mannemar Sønderskov, "Explaining Large-N Cooperation. Generalized Social Trust and the Social Exchange Heuristic," Rationality and Society 23 (2011) claims that, as a result of generalized trust, individuals rely in large-N cooperation problems on a social exchange heuristic.

55 Behavior is of course not necessarily socially minded. Individuals have been shown to be rivalistic see e.g. Wim B. Liebrand and Charles G. McClintock, "The Ring Measure of Social Values. A Computerized Procedure for Assessing Individual Differences in Information Processing and Social Value Orientation," European Journal of Personality 2 (1988). or spiteful see e.g. Klaus Abbink and Karim Sadrieh, "The Pleasure of Being Nasty," Economics Letters 105, no. 3 (2009). Containing such socially disruptive behavioral inclinations is an important task for institutions. But without allowing for socially beneficial behavioral inclinations, the dismal predictions of the prisoner's dilemma would go through. If this is what good-natured individuals experience or expect, many of them will shy away from acting in a socially beneficial manner see in particular Urs Fischbacher, Simon Gächter, and Ernst Fehr, "Are People Conditionally Cooperative? Evidence from a Public Goods Experiment," ibid.71 (2001).

56 On the behavior of such corporate actors see Christoph Engel, "The Behaviour of Corporate Actors. How Much Can We Learn from the Experimental Literature?," Journal of Institutional Economics 6 (2010). . 
reacting to information. Legal analysts and policymakers potentially have a lot to gain from applying these powerful conceptual tools to their problems, and by relying on the rich body of experimental evidence to predict the effect of legal interventions.

This transfer of tools and findings from economics, however, presupposes that the models that underlie the exercise are appropriate for the analysis of normative legal problems. This fit cannot be taken for granted. In economics, the models, and their experimental tests, have been created in an attempt at uncovering basic building blocks of human behavior. In the interest of cleanly identifying mechanisms and effects, the models are highly parsimonious. Experimental tests deliberately abstract from almost all features of the conflicts of life that motivate the investigation. They do so because random assignment to treatment only makes it possible to identify causal effects if baseline and treatment differ by no more than a single feature. The typical experiment completely removes context and exposes participants to a very simple, but usually strategic choice problem. An illustration is the simultaneous $2 \times 2$ prisoner's dilemma.

Many simplifications that are made for the sake of precise theorizing and rigorous testing seem to be at odds with the normative research question of lawyers. Lawyers intend to define the need for institutional intervention, and find the best institutional design, to address a conflict of life. These conflicts materialize in societies that are rich in informal and formal institutions. The citizens of modern countries never see the institution free state of nature that behavioral economics assumes.

In this paper I argue that the insights and findings from behavioral economics are nonetheless valuable for many, but not for all legal problems that could be modeled as simple games. These models are appropriate if citizens interact with each other without having any precise knowledge about the personality or individual context of their interaction partners. It is precisely the rich set of informal and formal institutions that makes room for such interaction. It has the effect of creating generalized trust. If individuals are sufficiently confident that nothing too bad will happen, they are freed up to interact with strangers as if they were in a state of nature.

I have spelt out my argument for conflicts of life that can be modeled as a simultaneous $2 \times 2$ prisoner's dilemma. But the argument equally holds for other simple games, like coordination problems. The critical question is not the definition of the game, but the willingness of individuals to take the risk of interaction without ex ante creating a relation-specific set of institutions. The willingness to do so is key for the success of modern societies. It dramatically reduces transaction cost, and increases division of labor. Yet since generalized trust is a precondition, these problems are not adequately modeled assuming that individuals exclusively care about personal profit. If that were the case, individuals would shy away from interacting with strangers whom they anticipate to exploit them. For understanding such situations, and for designing appropriate legal safeguards, it is essential to shift from neoclassical to behavioral law and economics. 